\title{
Article \\ Comparative Study of the Properties of Plasticized Polylactic Acid with Maleinized Hemp Seed Oil and a Novel Maleinized Brazil Nut Seed Oil
}

\author{
Aina Perez-Nakai ${ }^{1}$, Alejandro Lerma-Canto ${ }^{1}$ (D), Ivan Domingez-Candela ${ }^{2}$ (D), Daniel Garcia-Garcia ${ }^{1}(\mathbb{D}$, \\ Jose Miguel Ferri ${ }^{1}$ (D) and Vicent Fombuena ${ }^{1, *(\mathbb{D})}$ \\ 1 Technological Institute of Materials (ITM), Universitat Politècnica de València (UPV), Plaza Ferrándiz y \\ Carbonell 1, 03801 Alcoy, Spain; aipena@epsa.upv.es (A.P.-N.); allercan@epsa.upv.es (A.L.-C.); \\ dagarga4@epsa.upv.es (D.G.-G.); joferaz@upvnet.upv.es (J.M.F.) \\ 2 Instituto de Seguridad Industrial, Radiofísica y Medioambiental (ISIRYM), Universitat Politècnica de \\ València (UPV), Plaza Ferrándiz y Carbonell s/n, 03801 Alcoy, Spain; ivdocan@doctor.upv.es \\ * Correspondence: vifombor@upv.es
}

Citation: Perez-Nakai, A.;

Lerma-Canto, A.; Domingez-Candela,

I.; Garcia-Garcia, D.; Ferri, J.M.;

Fombuena, V. Comparative Study of the Properties of Plasticized Polylactic Acid with Maleinized Hemp Seed Oil and a Novel Maleinized Brazil Nut Seed Oil. Polymers 2021, 13, 2376. https://doi.org/10.3390/ polym13142376

Academic Editors: Andreia F. Sousa, José Miguel Ferri, Vicent

Fombuena Borràs and Miguel

Fernando Aldás Carrasco

Received: 30 June 2021

Accepted: 16 July 2021

Published: 20 July 2021

Publisher's Note: MDPI stays neutral with regard to jurisdictional claims in published maps and institutional affiliations.

Copyright: (c) 2021 by the authors. Licensee MDPI, Basel, Switzerland. This article is an open access article distributed under the terms and conditions of the Creative Commons Attribution (CC BY) license (https:// creativecommons.org/licenses/by/ $4.0 /)$.

\begin{abstract}
In this study, for the first time, Brazil nut seed oil was chemically modified with maleic anhydride to obtain maleinized Brazil nut seed oil (MBNO). The same process was developed to obtain maleinized hemp seed oil (MHO). The use of MBNO and MHO was studied as bio-based plasticizers by incorporating them with different contents ranging from 0 to $10 \mathrm{phr}$ in a polylactic acid (PLA) matrix. By means of mechanical, thermal and thermomechanical characterization techniques, the properties of the different formulations were studied to evaluate the plasticizing effect of the MBNO and MHO. With the addition of both plasticizers, a significant increase in ductile properties was observed, reaching an increase in elongation at break of $643 \%$ with $7.5 \mathrm{phr}$ MBNO and $771 \%$ with $10 \mathrm{phr}$ MHO compared to neat PLA. In addition, it has been observed that the mechanical resistant properties do not decrease, since the oils enhance the crystallization of PLA by increasing the free volume between its chains and counteracting the effect. Finally, a disintegration test was carried out under thermophilic conditions at $58{ }^{\circ} \mathrm{C}$ for 27 days, demonstrating that the incorporation of $\mathrm{MHO}$ and MBNO does not significantly affect the biodegradability of neat PLA.
\end{abstract}

Keywords: maleinized hemp seed oil; maleinized Brazil nut seed oil; bio-plasticizers; polylactic acid

\section{Introduction}

Since the end of the 20th century, environmental concerns and the development of sustainable strategies have been on the rise [1]. This concern carries over to the present day, where plastic represents a large part of human life, with up to 368 million tonnes of plastic produced globally in 2019 [2]. The problem arises mainly because of the negative impact on the ecosystems generated by the amount of plastic waste, since only 173 million tonnes are collected for recycling or landfill [3], but also by the exploitation of non-renewable natural resources, such as petroleum. The problem is magnified in the packaging industry, as it is the largest consumer of plastics, accounting for $39.6 \%$ of total plastic consumption in Europe [2]. In view of this situation, research is mainly focused on obtaining polymeric materials with formulations based on renewable resources or even with the property of being biodegradable. A wide variety of biopolymers or bio-based materials have now been obtained that contribute to this sustainable development.

Bio-based polymers are polymers that are made from biological substances, i.e., nonfossil materials [4]. These materials may or may not be biodegradable depending on their ability to be broken down by microorganisms [4]. Currently, some of the most promising biopolymers are extracted from biomass (starch, cellulose, protein, chitin, etc.), such as thermoplastic starches (TPSs), given the abundance of polysaccharides in the biomass. Another promising alternative are also those obtained by microbial production, such 
as polyhydroxyalkanoates (PHAs) and polyhydroxybutyrate (PHB) or polylactic acid (PLA) [5-7].

In 2020, bioplastics accounted for only 1.2 million tonnes, less than $1 \%$ of all plastics produced [3]. However, the market for these polymers has been growing for years and the trend is expected to increase, with production estimated to increase by $11.28 \%$ from 2019 to the end of 2025 [8]. Specifically, PLA is one of the biopolymers with the greatest potential for industrial use as a substitute for petroleum-based polymers $[9,10]$. This is due to its great potential due to the combination of its mechanical properties, easy processability and its price compared to other biopolymers [11,12]. PLA has a suitable thermal stability and resistance to being industrially processed by injection molding, welding, thermoforming or extrusion [13]. Moreover, as it is biodegradable, one of its most interesting applications is mainly in the packaging sector [14]. In terms of mechanical properties, this material is comparable to non-degradable polymers in the "commodity" range [14,15]. However, there is a major limitation of PLA, its brittleness, which is a major drawback in the packaging industry [16]. To alleviate this disadvantage, there are several proposals. One solution to improve the flexibility of this polymer is its blending with other polymers such as polyethylene glycol (PEG), thermoplastic starch (TPS) or polybutylene succinate-co-adipate (PBSA), among others. However, the lack of miscibility between the components makes it difficult to achieve this improvement in toughness $[5,11,17,18]$. For this reason, some authors proposed modified vegetable oils (MVOs) as compatibilizing agents or even as plasticizing additives $[12,19]$. The reason for this is that they are a renewable and sustainable substitute for synthetic modifiers [20,21], which are also respectful of human health due to their non-toxicity, as they do not generate the migration of substances such as Bisphenol A (BPA), as is the case with conventional epoxy resins used in consumer products [22].

Several techniques can be used for chemical modification, such as epoxidation $[23,24]$, maleinization $[5,10,25]$, acrylation or hydroxylation. The MVOs available on the market today are mainly epoxidized soybean oil (ESBO) [25] and epoxidized linseed oil (ELO) [26]. Authors such as Garcia-Garcia et al. or Chieng et al. [26,27] have reported the improvement of PLA stiffness properties with these oils. Additionally, other authors investigated other modified oils for PLA formulations such as epoxidized cottonseed oil (ECSO) [24] or epoxidized palm oil (EPO) [27]. Another commercial option is maleinized linseed oil, which has provided excellent properties to PLA, as reported Ferri et al. [28].

In this work, the chemical modification of process of oils carried out is the maleinization. Maleinization is a chemical process, usually carried out in a single step, which consists of incorporating maleic anhydride molecules into the triglycerides that make up vegetable oils when conjugated carbon-carbon double bonds are present. For this purpose, there are several methods that can be used, such as the so-called "ene" reaction, Diels-Alder addition and free radical copolymerization, the first being the most favorable and the one used in this work [5,29]. This procedure requires a temperature of about $200^{\circ} \mathrm{C}$ to result in the addition of the anhydric groups at the allylic positions of the fatty acid, as shown in Figure 1.

Both Brazil nut (Bertholletia excelsa) and hemp seed (Cannabis sativa L.) are interesting as MVOs, since both have an interesting lipid profile for functionalization. The Brazil nut is a brown fruit generally cultivated in the Amazon [30]. Its oil is an interesting object of study, since it has between $60.8 \%$ and $72.5 \%$ lipids [30,31]. Among them, it has $75.6 \%$ unsaturated fatty acids (UFA) [30], and both monounsaturated (MUFA) and polyunsaturated (PUFA), which means a significant amount of double bonds that allow its functionalization by chemical processes such as maleinization. On the other hand, hemp seed oil is also attractive for this purpose, as it is high in linoleic acid (55.3\%) and linolenic acid (20.3\%) [32]. Both allow their oil to be extracted by cold pressing with a good yield and also have good oxidative stability [31,33]. Thereupon, this work evaluates the potential of MBNO and MHO as a bio-based plasticizer to improve the ductile properties of PLA 
related to its brittleness and the comparison of these with commercial maleinized linseed oil (MLO).

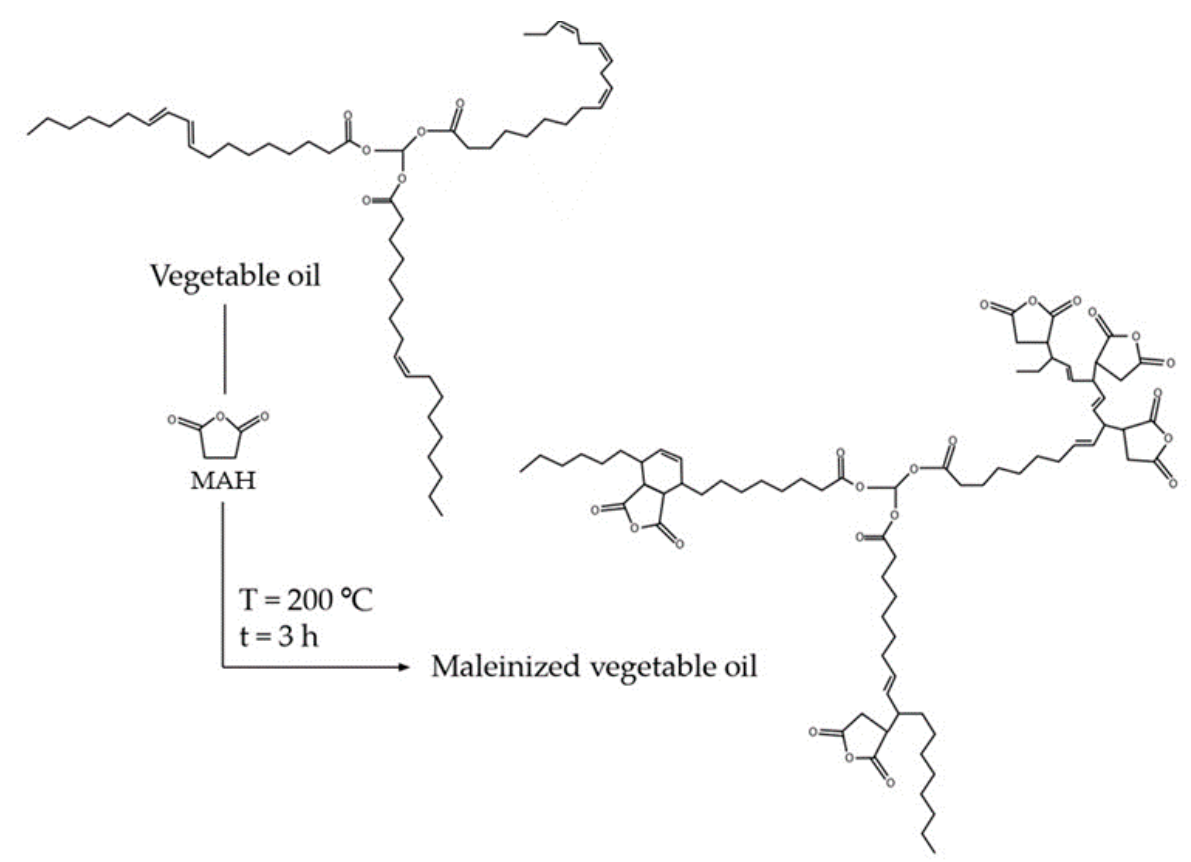

Figure 1. Schematic representation of the maleinization process of the triglyceride presents in vegetable oil.

\section{Materials and Methods}

\subsection{Materials}

The Brazil nuts used in this work were of Brazilian origin and were purchased from FrutoSeco (Alicante, Spain). On the other hand, the hemp seeds were obtained from a local market in Callosa de Segura (Alicante, Spain). The oil from both seeds was extracted by cold pressing with an extruder model DL-ZYJ05 purchased from Nanchang Dulong Industrial Company (Zucheng, China). The density of Brazil nut oil was $916 \mathrm{~kg} \cdot \mathrm{m}^{-3}$, its iodine value (IV) between 99.5 and $102.6 \mathrm{~g} 100 \mathrm{~g}^{-1}$ and its acid value (AV) $0.2 \mathrm{mg} \cdot \mathrm{KOH} \mathrm{g}^{-1}$. The density of hemp oil was $935 \mathrm{~kg} \cdot \mathrm{m}^{-3}$, its IV is $163.8 \mathrm{~g} \cdot 100 \mathrm{~g}^{-1}$ and its AV is $8 \mathrm{mg} \cdot \mathrm{KOH} \mathrm{g}{ }^{-1}$. For both cases, density, IV and AV values were obtained according to ISO 1675, ISO 3961 and ISO 660, respectively. For the maleinization of both oils, maleic anhydride supplied by Sigma Aldrich (Madrid, Spain), with a purity of $98 \%$ was used. The PLA used for mixing with the oils was a commercial-grade Ingeo Biopolymer 2003D from NatureWorks LLC (Minnetonka, MN, USA) in pellet form.

\subsection{Maleinization of Brazil Nut (Bertholletia excelsa) and Hemp (Cannabis sativa L.) Oils}

The same method was used for the maleinization of Brazil nut and hemp seed oil. For this purpose, a round flask with three necks with a capacity of $500 \mathrm{~mL}$ was used, where a stirrer was placed in the central neck and used at a speed of $300 \mathrm{rpm}$. A digital thermometer was placed in the second neck to measure the temperature during the process, and the extraction of samples and the introduction of maleic anhydride was carried out through the third neck. The maleinization ratio used was 2.4:1, following recommendations from previous works [5]. A total of $9 \mathrm{~g}$ of maleic anhydride per $100 \mathrm{~g}$ of each virgin oil was introduced. During the maleinization process, three temperature stages were used, at $180^{\circ} \mathrm{C}, 200{ }^{\circ} \mathrm{C}$ and $220^{\circ} \mathrm{C}$, and samples were taken every $30 \mathrm{~min}$. Initially, $300 \mathrm{~g}$ of oil was introduced into the round flask and when the first temperature of $180^{\circ} \mathrm{C}$ was reached, $1 / 3$ of the quantity of the total amount of maleic anhydride was added. This temperature was maintained for $1 \mathrm{~h}$ and increased to repeat the same at $200^{\circ} \mathrm{C}$ and $220^{\circ} \mathrm{C}$. Finally, the 
mixture was allowed to cool to room temperature. The degree of maleinization of the oil was determined according to ISO 660:2009 using the following expression:

$$
\text { Acid Value }=\frac{56.1 \times c \times V}{m}
$$

where $c$ is the exact concentration of the $\mathrm{KOH}$ standard solution used $\left(\mathrm{mol} \cdot \mathrm{L}^{-1}\right), V$ the volume of the $\mathrm{KOH}$ standard solution used $(\mathrm{mL})$ and $m$ the mass analyzed $(\mathrm{g})$.

\subsection{Manufacturing of PLA with Maleinized Vegetable Oils}

Several PLA compositions were made with different phr of MBNO and MHO, which are summarized in Table 1, where the codes assigned to each of them are indicated. Prior to mixing, the PLA was dried for $24 \mathrm{~h}$ at $40{ }^{\circ} \mathrm{C}$. The required amounts of PLA and oil were weighed and added, to be mixed manually. The mixtures were processed with a co-rotating twin-screw extruder ( $\mathrm{D}=30 \mathrm{~mm}$; $/ \mathrm{D}=20: 1)$ from DUPRA (Alicante, Spain), at a rotation speed of $40 \mathrm{rpm}$ with a temperature profile of $165^{\circ} \mathrm{C}, 168.5^{\circ} \mathrm{C}, 172.5^{\circ} \mathrm{C}$ and $175^{\circ} \mathrm{C}$ from the feed zone to die, respectively. The compositions obtained were cooled to room temperature, pelletized and dried at $40^{\circ} \mathrm{C}$ for $24 \mathrm{~h}$. Finally, each composition was shaped by injected molding from Mateu and Solé (Barcelona, Spain) at temperature profiles of $170^{\circ} \mathrm{C}, 180^{\circ} \mathrm{C}, 190^{\circ} \mathrm{C}$ and $200^{\circ} \mathrm{C}$ from the feed section to injection nozzle.

Table 1. Composition of plasticized PLA with different contents (phr) of maleinized vegetable oils and labeling of the formulations.

\begin{tabular}{cccc}
\hline Reference & PLA & $\begin{array}{c}\text { Maleinized Brazil Nut } \\
\text { Oil-MBNO }(\mathbf{p h r})\end{array}$ & $\begin{array}{c}\text { Maleinized Hemp Seed } \\
\text { Oil-MHO (phr) }\end{array}$ \\
\hline PLA & 100 & 0 & 0 \\
PLA + 2.5 MBNO & 100 & 2.5 & 0 \\
PLA + 5 MBNO & 100 & 5 & 0 \\
PLA + 7.5 MBNO & 100 & 7.5 & 0 \\
PLA + 10 MBNO & 100 & 10 & 0 \\
PLA + 2.5 MHO & 100 & 0 & 2.5 \\
PLA + 5 MHO & 100 & 0 & 5 \\
PLA + 7.5 MHO & 100 & 0 & 7.5 \\
PLA + 10 MHO & 100 & 0 & 10 \\
\hline
\end{tabular}

\subsection{Mechanical Characterization of PLA Formulations Plasticized with MBNO and MHO}

Several standardized tensile, flexural, impact and hardness tests were carried out to determine the mechanical properties of the different PLA compositions manufactured with the different types and proportions of MVOs. The tensile and flexural tests were performed according to ISO 527 and ISO 178, respectively, with an Ibertest ELIB 30 universal testing machine from SAE Ibertest (Madrid, Spain). For the tensile test, a crosshead speed of $10 \mathrm{~mm} \cdot \mathrm{min}^{-1}$ was used with a $5 \mathrm{kN}$ load cell. In the case of flexural test, the deformation rates were studied at $5 \mathrm{~mm} \cdot \mathrm{min}^{-1}$. Both tests were performed on at least 5 different samples of each material and the average values of the elongation at break (\%), tensile and flexural strength, and Young's modulus and flexural modulus were calculated. To determine the impact resistance by energy absorption, a $6 \mathrm{~J}$ Charpy pendulum from Metrotec S.A. (San Sebastian, Spain) was used. According to ISO 179, rectangular samples of $80 \times 10 \times 4 \mathrm{~mm}^{3}$ without notches were employed. Finally, a Shore D hardness tester model 673-D from J. Bot S.A. (Barcelona, Spain) was used to determine the hardness according to ISO 868. A minimum of 5 samples were used and the results shown are the obtained average.

\subsection{Thermal Analysis of PLA Formulations Plasticized with MBNO and MHO}

The thermal properties of PLA and plasticized PLA compositions were determined by differential scanning calorimetry (DSC) and thermogravimetric analysis (TGA). The glass transition temperature $\left(\mathrm{T}_{\mathrm{g}}\right)$, cold crystallization temperature $\left(\mathrm{T}_{\mathrm{cc}}\right)$ and melting temperature 
$\left(\mathrm{T}_{\mathrm{m}}\right)$ were obtained by DSC with a Mettler Toledo DSC 821 (Schwerzenbach, Switzerland). The test conditions were under nitrogen atmosphere (flow rate $66 \mathrm{~mL} \cdot \mathrm{min}^{-1}$ ) with a thermal program to remove thermal history consisting of a first heating from $30^{\circ} \mathrm{C}$ to $200{ }^{\circ} \mathrm{C}$ at $10^{\circ} \mathrm{C} \cdot \mathrm{min}^{-1}$, followed by a cooling to $30^{\circ} \mathrm{C}$ at $2{ }^{\circ} \mathrm{C} \cdot \mathrm{min}^{-1}$ and a last heating to $350{ }^{\circ} \mathrm{C}$ at $2{ }^{\circ} \mathrm{C} \cdot \mathrm{min}^{-1}$. Thermal transitions were determined from the second heating. The percentage crystallinity of each material was calculated using the following equation:

$$
X_{\mathcal{c}}(\%)=\frac{\Delta H_{m}-\Delta H_{c}}{w \Delta H_{m}^{o}} \times 100
$$

where $\Delta H_{m}$ is the enthalpy of fusion, $\Delta H_{c}$ the cold crystallization enthalpy, $w$ the mass fraction of the material and $\Delta H_{m}^{o}$ the enthalpy of fusion for a theoretical pure crystalline PLA structure, which was assumed to be $93 \mathrm{~J} \mathrm{~g}^{-1}$ [34].

TGA tests were carried out to determine the initial degradation temperature $\left(\mathrm{T}_{0}\right)$ and the maximum degradation temperature $\left(\mathrm{T}_{\max }\right)$. The equipment used was a TGA/SDTA 851 from Mettler Toledo (Schwerzenbach, Switzerland) and the samples (7-10 mg) were tested under nitrogen atmosphere (flow rate $66 \mathrm{~mL} \cdot \mathrm{min}^{-1}$ ) and heating from $30^{\circ} \mathrm{C}$ to $700{ }^{\circ} \mathrm{C}$ at $20^{\circ} \mathrm{C} \cdot \mathrm{min}^{-1} \cdot \mathrm{T}_{0}$ was determined at $5 \%$ mass loss, while $\mathrm{T}_{\max }$ was calculated from the first derivate of the TGA curves (DTG).

\subsection{Thermomechanical Characterization of PLA Formulations Plasticized with MBNO and MHO}

To analyze the changes in storage modulus $\left(\mathrm{G}^{\prime}\right)$ and damping factor, a dynamic thermo-mechanical analysis (DMTA) was performed with an oscillatory rheometer AR G2 from TA Instruments (New Castle, DE, EEUU), equipped with a clamp attachment for solid samples. The $40 \times 10 \times 4 \mathrm{~mm}^{3}$ rectangular samples were tested in torsion mode and subjected to a thermal program from $30^{\circ} \mathrm{C}$ to $130^{\circ} \mathrm{C}$ with a heating rate of $2{ }^{\circ} \mathrm{C} \cdot \mathrm{min}^{-1}$. The frequency was set at $1 \mathrm{~Hz}$ and the maximum deformation $(\gamma)$ was $0.1 \%$.

\subsection{Degree of Disintegration under Composting Conditions of PLA Formulations Plasticized with $M B N O$ and $M H O$}

The degree of disintegration of each compound was carried out according to the recommendations of the ISO 20200 standard. For this purpose, 7 different square samples for each compound of dimensions $25 \times 25 \times 1 \mathrm{~mm}^{3}$ were buried in controlled soil. Previously, samples were dried at $40{ }^{\circ} \mathrm{C}$ for $24 \mathrm{~h}$. To evaluate the disintegration process, samples were unburied on days $3,7,14,17,21,24$ and 27 , washed with distilled water, dried at $45^{\circ} \mathrm{C}$ for $24 \mathrm{~h}$ and weighed in an analytical balance. The degree of disintegration was calculated with the following equation given in ISO 20200:

$$
D=\frac{m_{i}-m_{r}}{m_{i}} \times 100
$$

where $m_{i}$ is the initial mass of the sample before the test and $m_{r}$ is the weight of the sample extracted from compost soil on different days after drying. Photographs were also taken of each sample recovered on the days indicated to also qualitatively assess the disintegration process.

\section{Results}

\subsection{Synthesis of Maleinized Hemp Seed Oil and Brazil Nut Oil}

The evolution of the $\mathrm{AV}$ values along the three temperature stages of $180^{\circ} \mathrm{C}, 20{ }^{\circ} \mathrm{C}$ and $220^{\circ} \mathrm{C}$ used throughout the maleinization process of $\mathrm{BNO}$ and $\mathrm{HO}$ has been plotted in Figure 2. Initially, the $\mathrm{AV}$ of $\mathrm{BNO}$ is $0.20 \mathrm{mg} \mathrm{KOH} \mathrm{g}^{-1}$ and $8 \mathrm{mg} \mathrm{KOH} \mathrm{g}^{-1}$ for the $\mathrm{HO}$. In both cases, it can be observed how these values increase significantly and analogously after the first hour at $180^{\circ} \mathrm{C}$ to approximately $47 \mathrm{mg} \mathrm{KOH} \mathrm{g}^{-1}$ and $50 \mathrm{mg} \mathrm{KOH} \mathrm{g}^{-1}$ for the $\mathrm{BNO}$ and $\mathrm{HO}$, respectively, indicating that maleinization is occurring. After two hours, at the second temperature of $200{ }^{\circ} \mathrm{C}$, another significant increment can be observed up to values close to $90 \mathrm{mg} \mathrm{KOH} \mathrm{g}^{-1}$ in the case of $\mathrm{BNO}$ and up to $80 \mathrm{mg} \mathrm{KOH} \mathrm{g}^{-1}$ in the 
case of $\mathrm{HO}$. Finally, at $220^{\circ} \mathrm{C}$, after three hours, there is a drastic increase in the AV up to $105 \mathrm{mg} \mathrm{KOH} \mathrm{g}^{-1}$ in $\mathrm{HO}$ and even up to $130 \mathrm{mg} \mathrm{KOH} \mathrm{g}^{-1}$ in BNO. In the two oils, the $\mathrm{AV}$ follows a very similar trend in which a clear increase is observed as the temperature increases. This is due to the fact that at temperatures close to $200{ }^{\circ} \mathrm{C}$, the "ene" reaction is favored, in which maleic anhydride can easily bind to an allylic position of the unsaturated fatty acid [35]. As the temperature of $220^{\circ} \mathrm{C}$ is maintained over time, the acidity index tends to stabilize, in the case of $\mathrm{HO}$ at $105 \mathrm{mg} \mathrm{KOH} \mathrm{g}^{-1}$ and at $130 \mathrm{mg} \mathrm{KOH} \mathrm{g}^{-1}$ for $\mathrm{BNO}$. Both values are in complete agreement with the $\mathrm{AV}$ of commercial MLO reported by Quiles-Carrillo et al. [36], which indicates that it ranges between 105 and $130 \mathrm{mg} \mathrm{KOH} \mathrm{g}^{-1}$, suggesting that both the $\mathrm{MBNO}$ and $\mathrm{MHO}$ developed have similar characteristics to one of the few maleinized oils available on the market today.

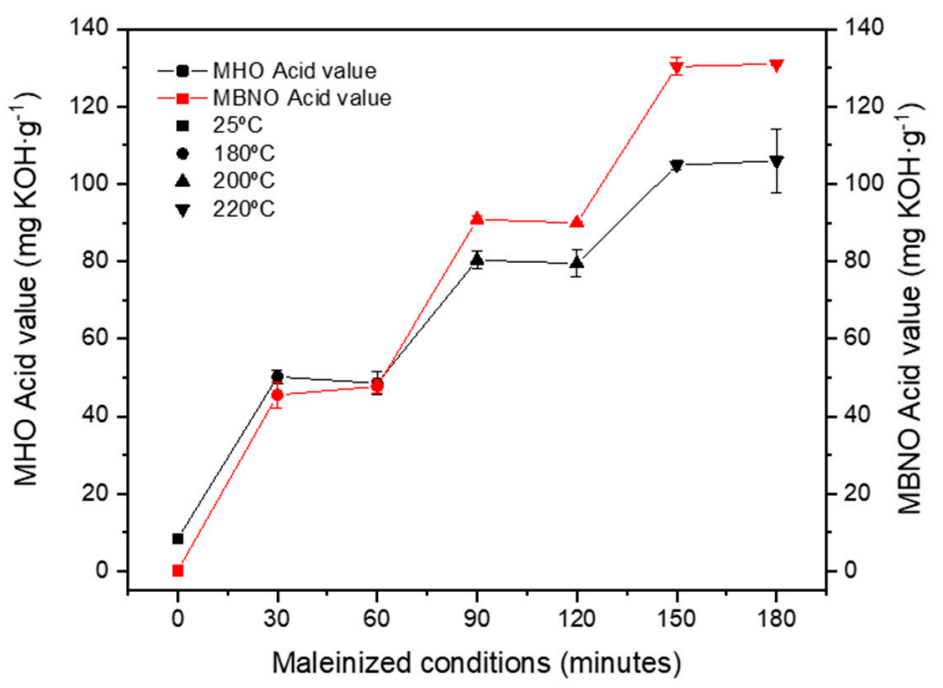

Figure 2. Effect of temperature and time on the efficiency of the maleinization of $\mathrm{HO}$ and BNO with maleic anhydride.

Another consequence observed as a result of the maleinization process is an important change in the color of the oils. Figure 3 shows a progressive color change of BNO, in which, at $180^{\circ} \mathrm{C}$, the color is light yellow, similar to the color of the original oil, and changes to a reddish color as maleinization occurs. The same occurs with HO. Ernzen et al. [37] reported a similar change during the maleinization process of soybean oil, in which the oil changed from a yellow to an orange-reddish color.

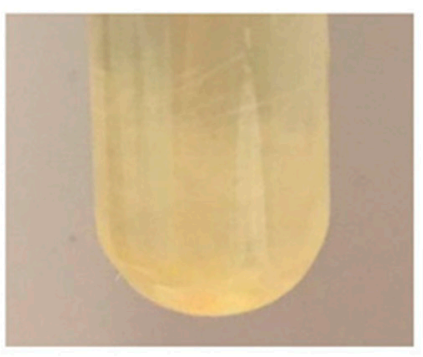

(a)

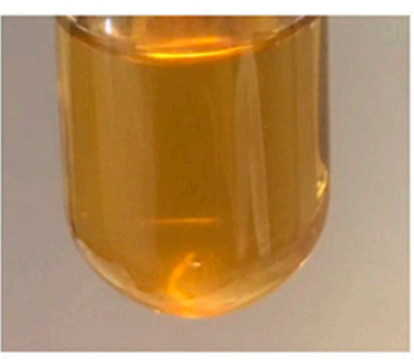

(b)

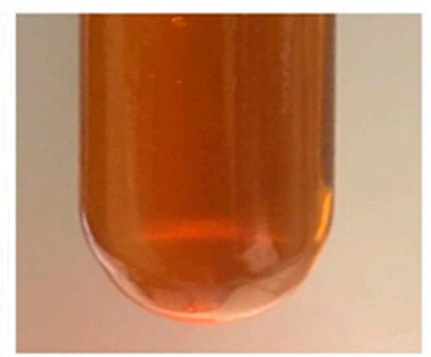

(c)

Figure 3. Influence of the reaction temperature and time on the color during maleinization of BNO, (a) $180{ }^{\circ} \mathrm{C}-0 \mathrm{~min},(\mathbf{b}) 200{ }^{\circ} \mathrm{C}-120 \mathrm{~min}$ and (c) $220^{\circ} \mathrm{C}-180 \mathrm{~min}$.

\subsection{Effect of MBNO and MHO on Mechanical Properties of Plasticized PLA Formulations}

The results obtained from the mechanical properties of the different PLA formulations with both MBNO and MHO show a significant reduction in PLA stiffness, indicating that both oils are effective as renewable PLA plasticizers. Figure 4 shows the tensile mechanical 
properties of PLA with MBNO and MHO. Unplasticized PLA has a Young's modulus close to $3000 \mathrm{MPa}(2977 \pm 21 \mathrm{MPa})$ and a tensile strength of $35.8 \pm 7.3 \mathrm{MPa}$, relatively high values in the thermoplastic commodity range. However, its toughness is low because it shows an elongation at break of $7.4 \pm 7 \%$. By incorporating MBNO into the PLA matrix, an increase in elongation is observed from $2.5 \mathrm{phr}$, reaching the maximum value of $52 \%$ $\pm 3.0 \%$ at $7.5 \mathrm{phr}$, which represents an increase of $643 \%$ with respect to neat PLA. From this concentration of $\mathrm{MBNO}$, a decrease in elongation occurs, probably due to plasticizer saturation, a phenomenon that some authors call an anti-plasticization effect [38]. On the other hand, the effect of MHO on the elongation at break is observed from $7.5 \mathrm{phr}$ MHO where it increases drastically up to $42 \% \pm 6 \%$ and even increases up to $61 \% \pm 3.0 \%$ with the addition of $10 \mathrm{phr} \mathrm{MHO}$, i.e., $771 \%$ more than neat PLA. These results obtained are close to the results reported by Ferri et al. [28], in which an elongation of $78.4 \%$ was obtained by incorporating commercial MLO into PLA. In Figure 5, it is possible to observe the changes in the appearance of the different tensile specimens after the test. Figure $5 \mathrm{a}$ shows specimens made with different MBNO contents. It can be seen how from $7.5 \mathrm{phr}$ of MBNO content, the specimen has a lower final elongation. Figure $5 b$ shows the specimens with different $\mathrm{MHO}$ contents after the tensile test. The main difference with respect to MBNO is observed in the PLA $+10 \%$ MHO sample, whose elongation is higher than that obtained with $7.5 \mathrm{phr}$ MHO. This increase in elongation at break is due to the enhancement of molecular mobility, which is explained by several plasticization theories. The first of these, the lubricity theory, holds that the plasticizer functions as a molecular lubricant of the polymer. On the other hand, gel theory, applied to amorphous thermoplastics such as the grade of PLA used in this work, suggests that the plasticizer molecules are placed between the polymer chains and weaken the interactions between them. Finally, the free volume theory argues that the plasticizer increases the free volume and thus decreases the interactions between the polymer chains [39].

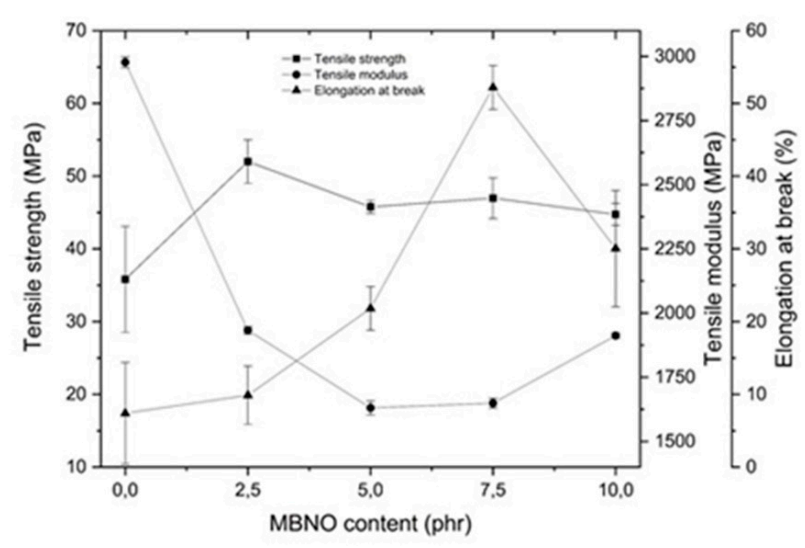

(a)

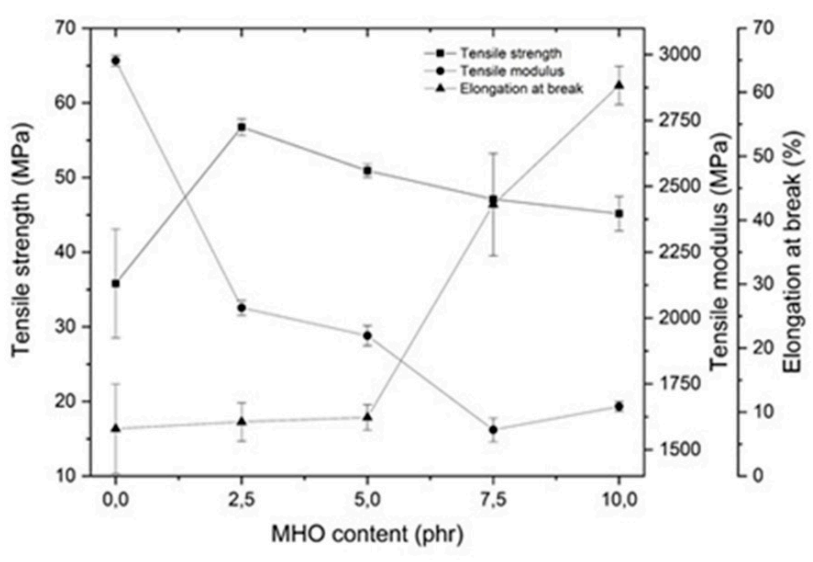

(b)

Figure 4. Plot of evolution of tensile properties of PLA formulations plasticized with various contents of MBNO (a) and $\mathrm{MHO}(\mathbf{b})$.

In addition, with the incorporation of both oils, an increase in tensile strength is observed with $2.5 \mathrm{phr}$, with respect to neat PLA, and then a decreasing trend as the percentage of oil incorporation increases. Several authors report a similar effect, but with lower strength values than PLA as an oil content increases. Garcia-Garcia et al. [40] reported a decrease in strength from $46.5 \mathrm{MPa}$ to $42.2 \mathrm{MPa}$ with the addition of $10 \%$ epoxidized karanja oil-EKO. In the case of $\mathrm{MBNO}$ and $\mathrm{MHO}$, by incorporating between 2.5 and $10 \mathrm{phr}$, higher strengths were obtained than those of neat PLA, counterbalanced, in turn, by an improvement in its elongation. This phenomenon can be explained by the fact that $\mathrm{MHO}$ and MBNO, by improving the mobility between PLA chains, also facilitate crystallization [41], which at the same time generates an increase in its stiffness. Finally, Young's modulus follows a decreasing trend in both cases, obtaining the lowest value 
with the incorporation of 5 phr MBNO of up to $45.2 \%$ and with 7.5 phr MHO of up to $47 \%$. From these contents in phr, the modulus tends to increase as the elongation tends to decrease. This decreasing evolution is in line with the results reported by authors such as Carbonell-Verdu et al. [24], who with the incorporation of ECSO to PLA obtained a reduction in the tensile modulus of $47.5 \%$ with respect to neat PLA. The high decrease in tensile modulus obtained with $\mathrm{MBNO}$ and $\mathrm{MHO}$ is related to the decrease in molecular interactions that facilitate movement.

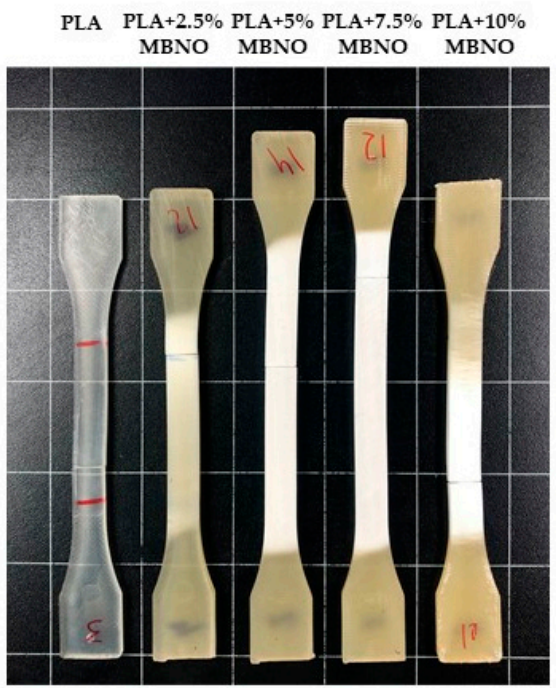

(a)

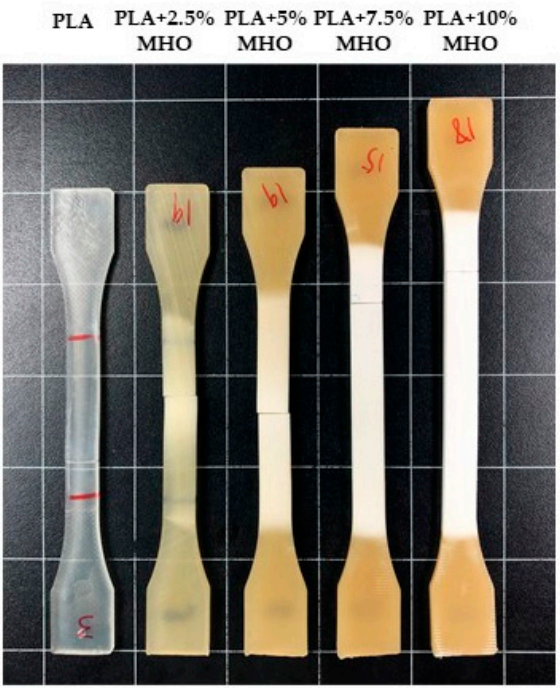

(b)

Figure 5. Plot of evolution of tensile properties of PLA formulations plasticized with various contents of MBNO (a) and $\mathrm{MHO}(\mathbf{b})$.

In parallel, Figure 6 shows a decrease in strength and flexural modulus as MBNO and $\mathrm{MHO}$ content increases. In the case of $\mathrm{MBNO}$, a maximum reduction in flexural strength of $37.7 \%$ and flexural modulus of $20 \%$ is obtained with $10 \mathrm{phr}$ and $39.6 \%$ and $18.4 \%$, respectively, with $10 \mathrm{phr} \mathrm{MHO}$ content. However, as with the tensile properties, it is at 5 phr MBNO and 7.5 phr MHO that the decrease in strength and modulus tends to stabilize, suggesting plasticizer saturation. Ferri et al. [28] reported a decrease in the flexural strength of PLA with commercial MLO of up to $24 \%$, and also a saturation around 15 phr MLO. The antiplasticizing effect of polymers depends, above all, on the molecular weight and the concentration of the diluent, so that in each formulation it is produced with a specific percentage of plasticizer [42].

On the other hand, Figure 7 summarizes the energy absorbed by Charpy's impact test and the Shore D hardness of neat PLA and formulations. The energy absorbed by Charpy's impact test is closely related to the toughness of the material; therefore, it is also representative for evaluating the effectiveness of $\mathrm{MBNO}$ and $\mathrm{MHO}$ as a plasticizer. Due to its brittleness, neat PLA has a relatively low absorbed energy (around $35.5 \mathrm{~kJ} \cdot \mathrm{m}^{-2}$ ). By adding plasticizers, an increase in absorbed energy is observed, in the case of MBNO up to $20 \%$ higher and in the case of $\mathrm{MHO}$ up to $46 \%$ higher. The energy absorbed by a material depends both on the deformation capacity linked to the ductility properties and on the breaking strength, which is related to the mechanical properties [28]; therefore, the results are in full agreement with the obtained values of elongation, modulus and breaking strength. As for hardness, the value decreases progressively as more plasticizer is incorporated, although it is not as strongly visualized as with other properties. With MBNO the Shore D hardness decreased from 80 to 71.7 at 7.5 phr MBNO, and with 10 phr $\mathrm{MHO}$ to 72.9. Other studies reported a similar decrease from 75.6 to 59.6 with the addition of $22.5 \%$ commercial ELO to PLA/hazelnut shell flour (HSF) blends [43]. 


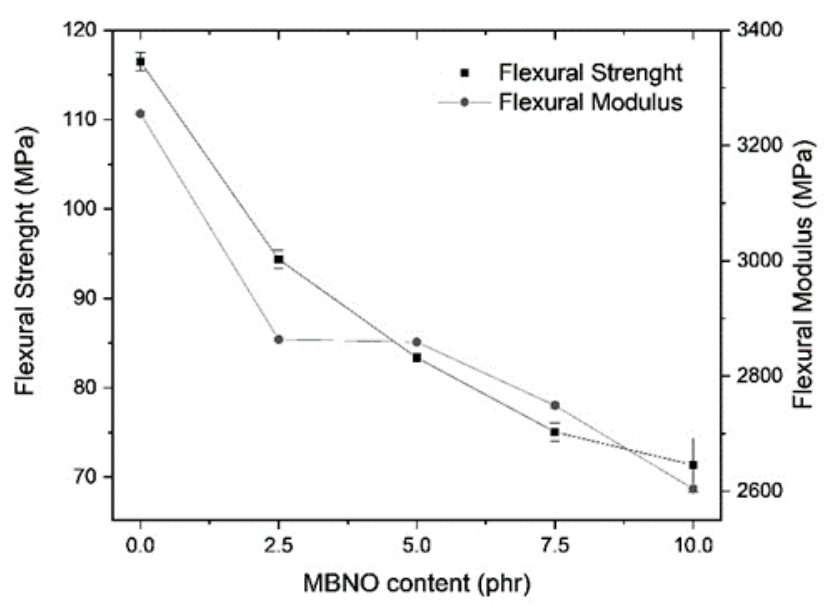

(a)

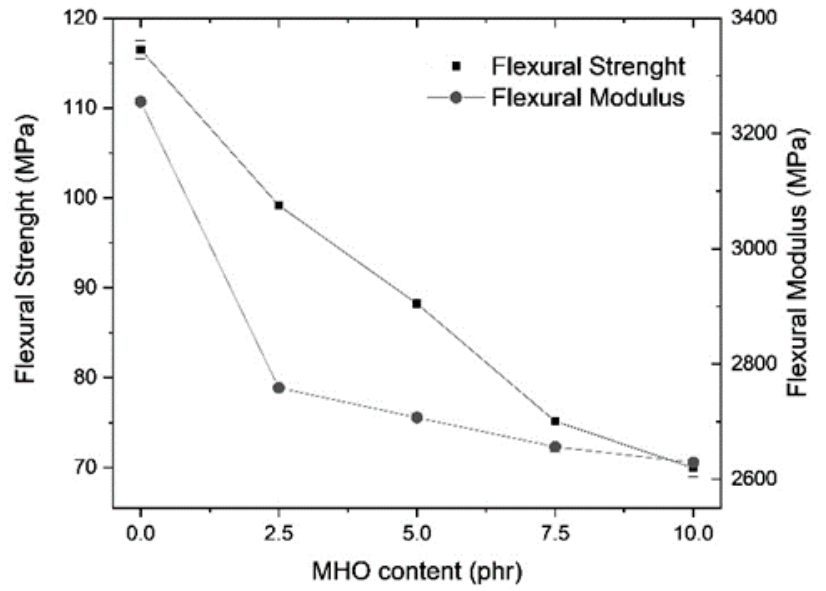

(b)

Figure 6. Plot of evolution of flexural properties of PLA formulations plasticized with various contents of MBNO (a) and $\mathrm{MHO}(\mathbf{b})$.

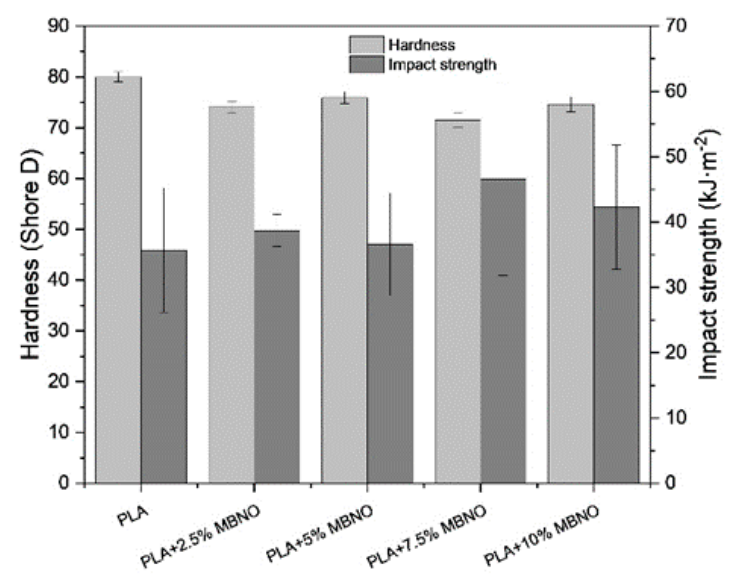

(a)

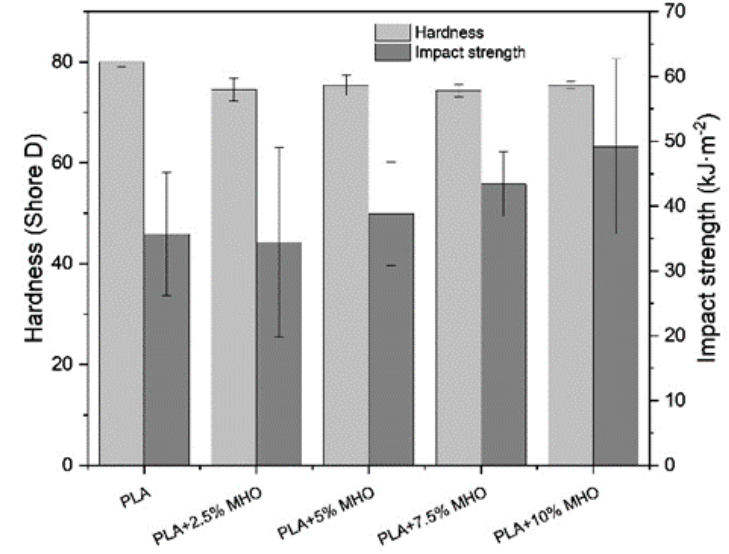

(b)

Figure 7. Graphic representation of impact strength and hardness (Shore D) of PLA formulations plasticized with various contents of MBNO (a) and $\mathrm{MHO}(\mathbf{b})$.

\subsection{Effect of $M B N O$ and $M H O$ on Thermal Properties of Plasticized PLA Formulations}

Thermal stability of PLA and plasticized formulations with different content of MBNO and $\mathrm{MHO}$ was performed by thermogravimetry analysis (TGA). Figure 8 show the weight loss versus temperature curves for each sample (TG) and their corresponding first derivative curves (DGT). Table 2 shows some characteristic thermal parameters of the thermograms, such as the degradation onset temperature $\left(\mathrm{T}_{5 \%}\right)$, which indicates the temperature at which a $5 \%$ weight loss occurs, and the maximum degradation temperature $\left(T_{\max }\right)$, which corresponds to the peak of the first derivative curve. Neat PLA possesses good thermal stability with a $\mathrm{T}_{5 \%}$ of $347.9^{\circ} \mathrm{C}$ and a $\mathrm{T}_{\max }$ of $386^{\circ} \mathrm{C}$. As can be seen, adding $\mathrm{MBNO}$ or MHO to PLA causes a slight decrease in $\mathrm{T}_{5 \%}$ as they are incorporated in higher quantities. In this case, the addition of $10 \mathrm{phr} \mathrm{MNBO}$ results in a $\mathrm{T}_{5 \%}$ reduction of $4.5^{\circ} \mathrm{C}$, while with $10 \mathrm{phr} \mathrm{MHO}$, the reduction is $10.1^{\circ} \mathrm{C}$. Regarding the maximum degradation temperature, it can be observed that both plasticizers lead to a decrease in temperature, obtaining the lowest value at $10 \mathrm{phr}$, with a reduction of $16.4{ }^{\circ} \mathrm{C}$ for both plasticizers. Similar behavior was observed by Garcia-Campo et al. [44] for PLA/PHB/PCL blends compatibilized with epoxidized soybean oil (ELO). The authors observed how the addition of ELO into the blend resulted in a reduction in $\mathrm{T}_{5 \%}$ by $19.1{ }^{\circ} \mathrm{C}$ and $\mathrm{T}_{\max }$ by $20^{\circ} \mathrm{C}$. 


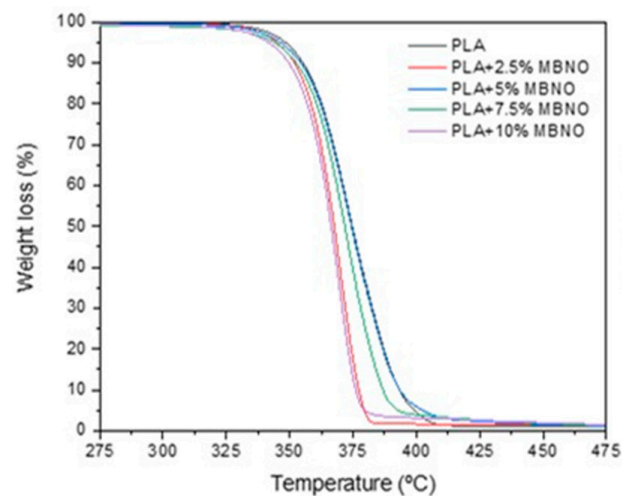

(a)

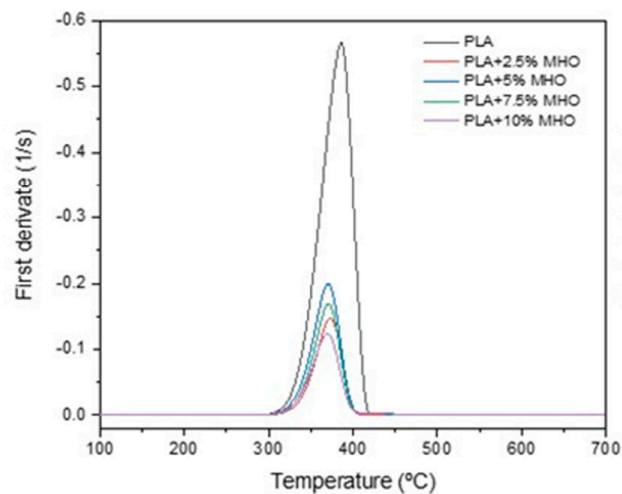

(c)

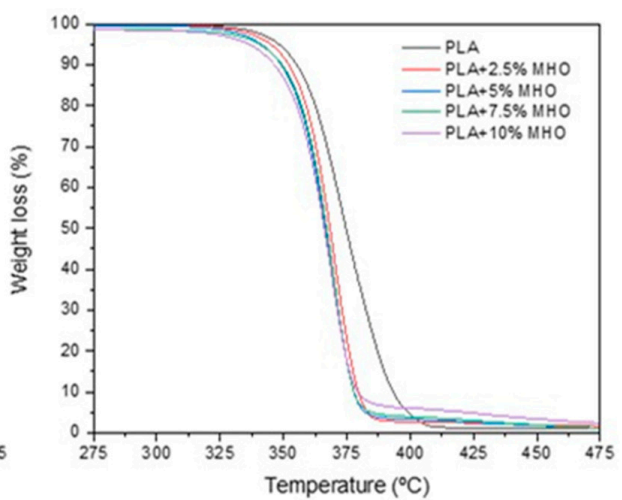

(b)

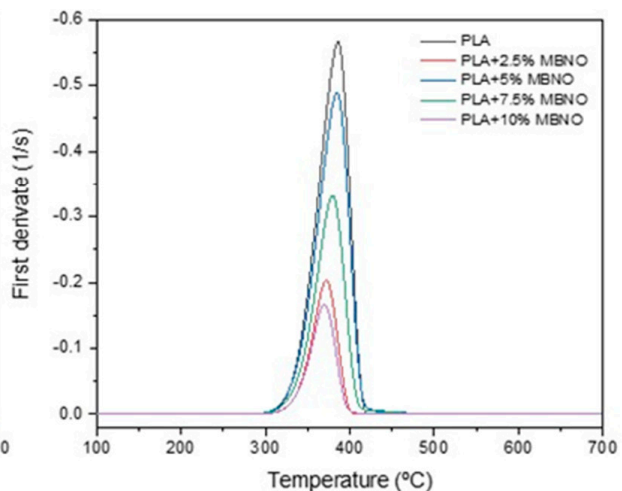

(d)

Figure 8. TGA $(\mathbf{a}, \mathbf{b})$ and DTGA $(\mathbf{c}, \mathbf{d})$ of unplasticized PLA and PLA plasticized with different content of MBNO and MHO.

Table 2. Summary of the TGA and DSC thermal parameters of PLA unplasticized and plasticized with different amounts of $\mathrm{MBNO}$ and MHO content.

\begin{tabular}{|c|c|c|c|c|c|c|c|c|}
\hline \multirow[b]{2}{*}{ Samples } & \multicolumn{2}{|c|}{ TGA Parameters } & \multicolumn{6}{|c|}{ DSC Parameters } \\
\hline & $\mathrm{T}_{5 \%}\left({ }^{\circ} \mathrm{C}\right)[\mathrm{a}]$ & $\mathrm{T}_{\max }\left({ }^{\circ} \mathrm{C}\right)$ & $\mathrm{T}_{\mathrm{g}}\left({ }^{\circ} \mathrm{C}\right)$ & $\mathrm{T}_{\mathrm{cc}}\left({ }^{\circ} \mathrm{C}\right)$ & $\Delta \mathrm{H}_{\mathrm{c}}\left(\mathrm{Jg}^{-1}\right)$ & $\mathrm{T}_{\mathrm{m}}\left({ }^{\circ} \mathrm{C}\right)$ & $\mathrm{AH}_{\mathrm{m}}\left(\mathrm{Jg}^{-1}\right)$ & $\begin{array}{c}X_{\text {PLA }} \\
(\%)\end{array}$ \\
\hline PLA & 347.9 & 386.2 & 61.0 & 123.64 & 1.2 & 150.7 & 3.2 & 1.7 \\
\hline $\mathrm{PLA}+2.5 \% \mathrm{MBNO}$ & 346.6 & 372.1 & 58.0 & 100.8 & 24.9 & 153.3 & 26.8 & 2.1 \\
\hline $\mathrm{PLA}+5 \% \mathrm{MBNO}$ & 346.5 & 384.6 & 57.9 & 120.8 & 9.2 & 150.3 & 15.0 & 5.8 \\
\hline $\mathrm{PLA}+7.5 \% \mathrm{MBNO}$ & 344.5 & 379.3 & 58.7 & 123.7 & 3.3 & 151.2 & 10.0 & 6.8 \\
\hline PLA + 10\%MBNO & 343.4 & 369.6 & 57.8 & 123.5 & 2.6 & 151.0 & 3.2 & 7.3 \\
\hline $\mathrm{PLA}+2.5 \% \mathrm{MHO}$ & 346.9 & 373.1 & 57.8 & 103.1 & 21.0 & 153.3 & 22.6 & 1.6 \\
\hline $\mathrm{PLA}+5 \% \mathrm{MHO}$ & 342.9 & 370.6 & 56.8 & 101.8 & 20.8 & 153.6 & 28.4 & 7.5 \\
\hline PLA + 7.5\% MHO & 342.2 & 370.6 & 57.3 & 113.9 & 13.5 & 150.5 & 19.5 & 6.0 \\
\hline PLA + 10\% MHO & 337.8 & 369.6 & 56.9 & 109.9 & 9.7 & 149.2 & 20.3 & 10.6 \\
\hline
\end{tabular}

[a] $\mathrm{T}_{5 \%}$, calculated at $5 \%$ mass loss.

Table 2 shows the main thermal properties obtained by DSC. On the other hand, Figure 9 shows the plot representation of the dynamic curve of DSC obtained with the unplasticized PLA and PLA plasticized with different contents of MBNO and MHO. As can be seen, both maleinized oils have a direct effect on some thermal properties of PLA. Unplasticized PLA has a glass transition temperature $\left(\mathrm{T}_{\mathrm{g}}\right)$ located at $61^{\circ} \mathrm{C}$, a cold crystallization temperature $\left(\mathrm{T}_{\mathrm{cC}}\right)$ at $123.6^{\circ} \mathrm{C}$ and a melting temperature located at $150.7^{\circ} \mathrm{C}$. Both plasticizers, MBNO and $\mathrm{MHO}$, decrease the $\mathrm{T}_{\mathrm{g}}$ and $\mathrm{T}_{\mathrm{cc}}$ of PLA, which is indicative of an increase in the mobility of the polymer chains at lower temperatures, evidencing the plasticizing effect of both maleinized oils [45]. The same evolution was reported by Dominguez-Candela et al. [46], who employed 
epoxidized chia oil (ECO) in PLA. On the other hand, no significant variations were observed in $T_{m}$, showing that after the addition of the plasticizers, the $T_{m}$ remained at values around $150-153{ }^{\circ} \mathrm{C}$ for all the samples. As it is possible to observe in Figure 9, the addition of lower contents of maleinized oils provides two small melting temperature peaks, which are associated to the formation of two regions with different crystallinities, a result of the compatibilization process between the PLA matrix and the plasticizer. The addition of higher oil contents broadens these two peaks, producing an overlap between them. Regarding crystallinity, it is observed that PLA without plasticizing has a crystallinity of $1.7 \%$, whereas as MBNO or MHO is added, the crystallinity increases progressively. As can be seen in Table 2, with a $10 \mathrm{phr}$ MBNO, the crystallinity of PLA increases to $7.3 \%$, while with the $10 \mathrm{phr} \mathrm{MHO}$, it increases to $10.6 \%$. A similar increase was reported by Carbonell-Verdu et al. [5], who observed that the addition of $10 \mathrm{phr}$ commercial MLO and MCSO to PLA increased its crystallinity up to $11.6 \%$ and $19.1 \%$, respectively. The increase in crystallinity with the addition of plasticizers, in this case $\mathrm{MBNO}$ and $\mathrm{MHO}$, is caused by the facilitation of the laminar rearrangement of the amorphous zones of PLA, which is caused by the increased mobility of the polymer chains [47].

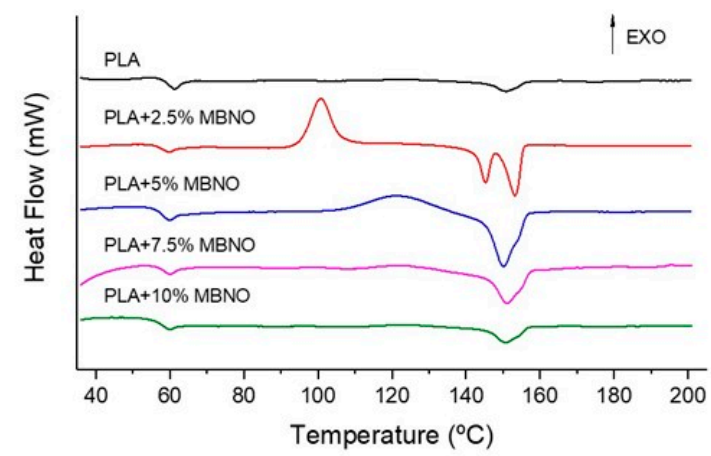

(a)

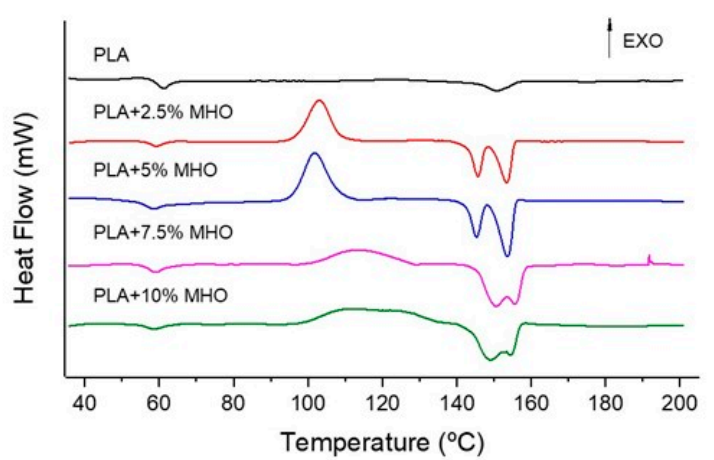

(b)

Figure 9. Dynamic DSC curve of PLA unplasticized and plasticized with different amounts of MBNO (a) and MHO content (b).

\subsection{Effect of MBNO and MHO on Thermomechanical Properties of Plasticized PLA Formulations}

The evolution of the storage modulus $\left(G^{\prime}\right)$ as a function of temperature is shown in Figure 10a,b. Neat PLA, at room temperature, has a storage modulus above $1000 \mathrm{MPa}$ and this remains constant up to $60^{\circ} \mathrm{C}$. With the incorporation of MBNO and MHO in the PLA matrix, no significant changes are observed in terms of $\mathrm{G}^{\prime}$ at room temperature, since in all of them the values remain between 900 and $1100 \mathrm{MPa}$, although it is observed that with the incorporation of the plasticizers, the $G^{\prime}$ tends to decrease slightly, showing its plasticizer effect. This is followed by a drop in $G^{\prime}$ of up to three orders of magnitude, a change that is related to $\mathrm{T}_{\mathrm{g}}$. In this case, a significant difference can be observed between the plasticized samples and neat PLA. As can be seen after the addition of $10 \mathrm{phr}$ MBNO, the $\mathrm{T}_{\mathrm{g}}$ decreases from $60{ }^{\circ} \mathrm{C}$ to $48^{\circ} \mathrm{C}$ and to almost $50{ }^{\circ} \mathrm{C}$ with $7.5 \mathrm{phr} \mathrm{MHO}$. The almost $10{ }^{\circ} \mathrm{C}$ shift in $\mathrm{T}_{\mathrm{g}}$ with both plasticizers is due, as described above, to the fact that the plasticizer generates an increase in the free volume, which improves the mobility of the chain due to a lower interaction between them, being able to move with lower energy [45]. Neat PLA above $75{ }^{\circ} \mathrm{C}$ behaves like an elastomer up to $95-100{ }^{\circ} \mathrm{C}$. Above this temperature, the energetic conditions favor and promote crystallization, improving the elastic behavior and leading to an increase in the storage modulus up to $60 \mathrm{MPa}$. Here, again, differences are observed when incorporating the plasticizers into PLA. As can be seen, this temperature decreases by around $10{ }^{\circ} \mathrm{C}$ in all the MBNO-plasticized formulations and by around $5{ }^{\circ} \mathrm{C}$ in the MHO-plasticized samples with respect to neat PLA. This decrease in temperature is due to the higher mobility of the chains, which allows their rearrangement into a packed structure with lower energy [48]. 


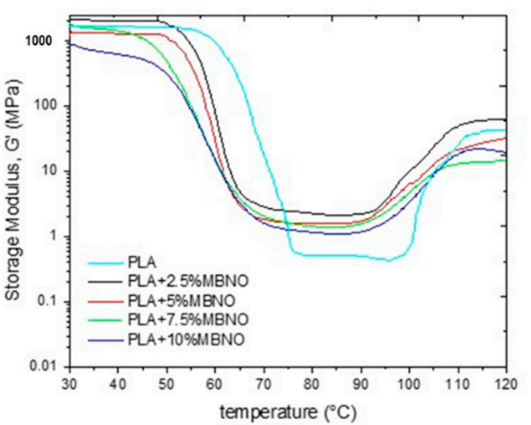

(a)

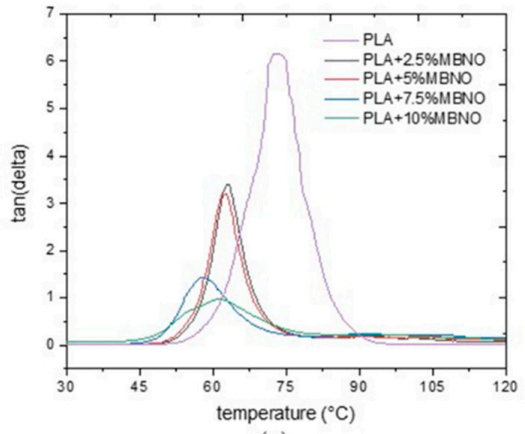

(c)

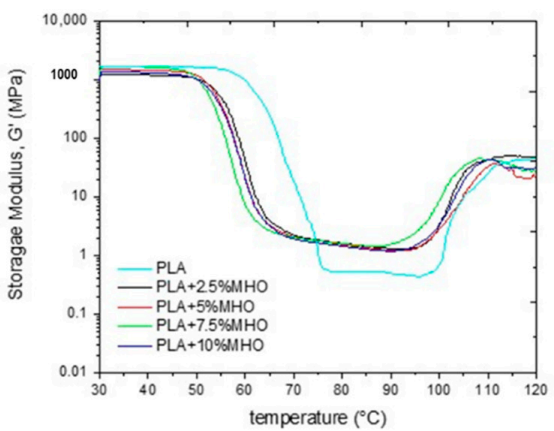

(b)

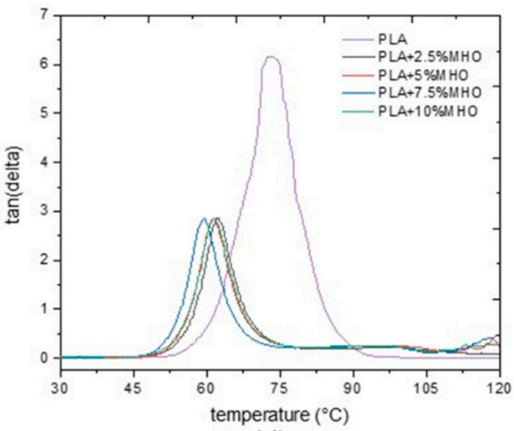

(d)

Figure 10. Storage modulus $(\mathbf{a}, \mathbf{b})$ and damping factor $(\mathbf{c}, \mathbf{d})$ of unplasticized PLA and PLA plasticized with different content of $\mathrm{MBNO}$ and $\mathrm{MHO}$ as a function of temperature.

The damping factor $(\tan \delta)$, which represents the energy lost due to viscous behavior relative to the energy stored due to elastic behavior, is shown in Figure 10c, d. The peak $\tan \delta$, is a way to obtain the $\mathrm{T}_{\mathrm{g}}$ value of the materials and, as can be seen, while that of neat PLA is around $73{ }^{\circ} \mathrm{C}$, in the formulations plasticized with MBNO and MHO, this temperature decreases to $58{ }^{\circ} \mathrm{C}$ and $60^{\circ} \mathrm{C}$ for samples plasticized with $7.5 \mathrm{phr} \mathrm{MBNO}$ and $\mathrm{MHO}$, respectively. Santos et al. [49] observed a similar decrease in $\mathrm{T}_{\mathrm{g}}$ with the addition to $10 \mathrm{wt} . \%$ and $20 \mathrm{wt} . \%$ of oligoesters obtained from sunflower oil biodiesel in PLA. The authors observed that the $\mathrm{T}_{\mathrm{g}}$ of PLA decreased from $62{ }^{\circ} \mathrm{C}$ to $52{ }^{\circ} \mathrm{C}$ and $44{ }^{\circ} \mathrm{C}$, respectively.

\subsection{Disintegration under Composting Condition of PLA Formulations}

The disintegration process of PLA formulations with MBNO and MHO in compost soil is shown visually in Figures 11 and 12, respectively. Initially, the samples were translucent in all formulations; however, after 3 days of incubation, a change in visual appearance to opaque was observed. This may be due to several factors. One cause can be attributed to the $50 \%$ relative humidity test condition, since possible hydrolytic degradation due to water absorption affects the refractive index [50]. On the other hand, taking into account the fact that the test was carried out under thermophilic conditions at $58^{\circ} \mathrm{C}$, the opacity may also be due to crystallization, since this temperature is close to the $\mathrm{T}_{\mathrm{g}}$ obtained in the thermal study by DSC. As can be seen in Figure 13, where the weight loss with respect to the initial mass at different periods of incubation for two PLA formulations with MBNO (a) and MHO (b) after 7 days was buried, the samples began to lose mass, which led to increased embrittlement, which is observed in the images with the appearance of cracks. However, it was not until day 14 that significant weight loss and inconsistency of the samples was observed. In the case of neat PLA, a faster degradation than in the plasticized PLA was observed, since on day 17 it had already exceeded $90 \%$ mass loss, the degree of disintegration determined by the ISO 20200 standard for considering a material to be disintegrable. In the case of plasticized PLA, in the formulations with $2.5 \mathrm{phr}$ and $5 \mathrm{phr}$ of both $\mathrm{MBNO}$ and $\mathrm{MHO}, 90 \%$ mass loss was reached at day 27 , while with the $7.5 \mathrm{phr}$ and $10 \mathrm{phr}$ formulations, it was reached at day 24 . Although the difference in the disintegration time of PLA formulations 
with plasticizer is small, and in all cases, the time is longer than with neat PLA, and a slight increase in the disintegration rate is observed when more plasticizer is added. This delay in disintegration with respect to neat PLA when introducing plasticizer is due to the fact that the PLA grade used in this work is very amorphous, as can be seen in the thermal analysis; when introducing plasticizer, crystallinity increases, making it difficult for microorganisms to act in the degradation, which act faster in amorphous domains [51,52]. A similar trend was reported by Balart et al. [53], who observed an increase in disintegration time upon the incorporation of ELO into the PLA matrix. Therefore, in view of the results, as a conclusion of the disintegration study, it has been demonstrated that the maleinized oils slightly retard the disintegration of PLA samples. However, PLA compounds plasticized with MBNO and $\mathrm{MHO}$ can be considered equally biodegradable by composting.

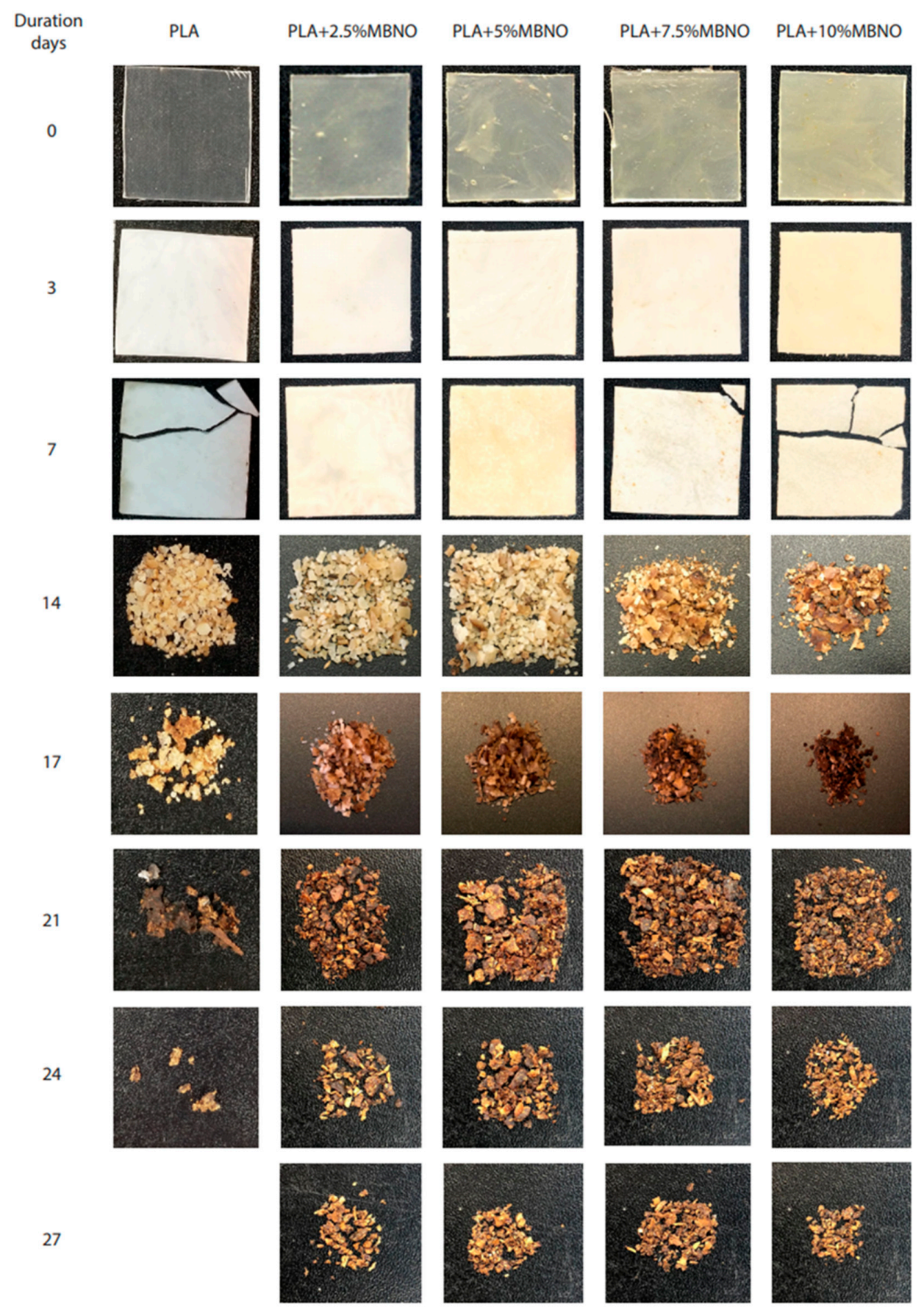

Figure 11. Visual appearance of disintegration under composting conditions of PLA and PLA plasticized with different contents of MBNO. 


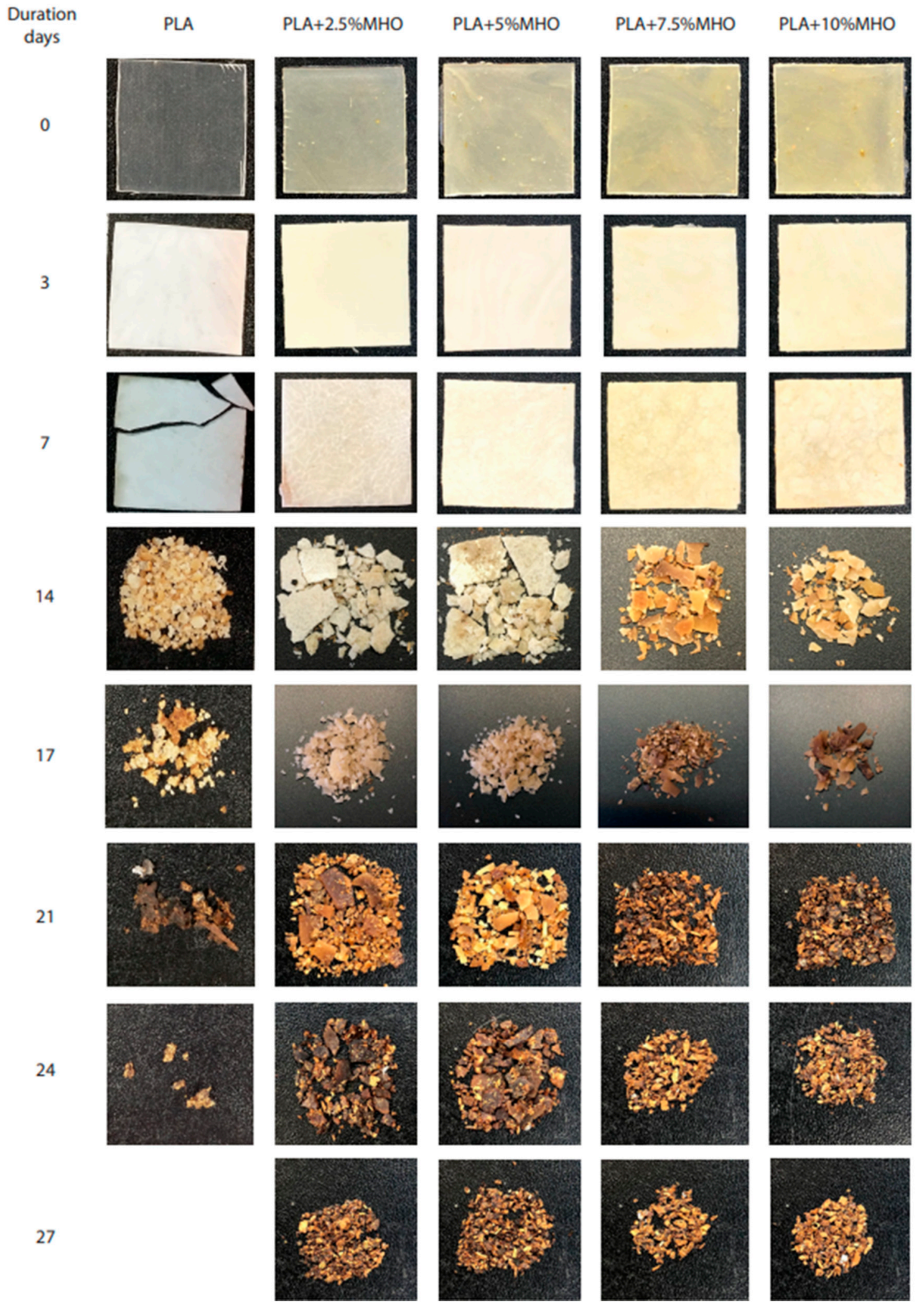

Figure 12. Visual appearance of disintegration under composting conditions of PLA and PLA plasticized with different contents of MHO. 


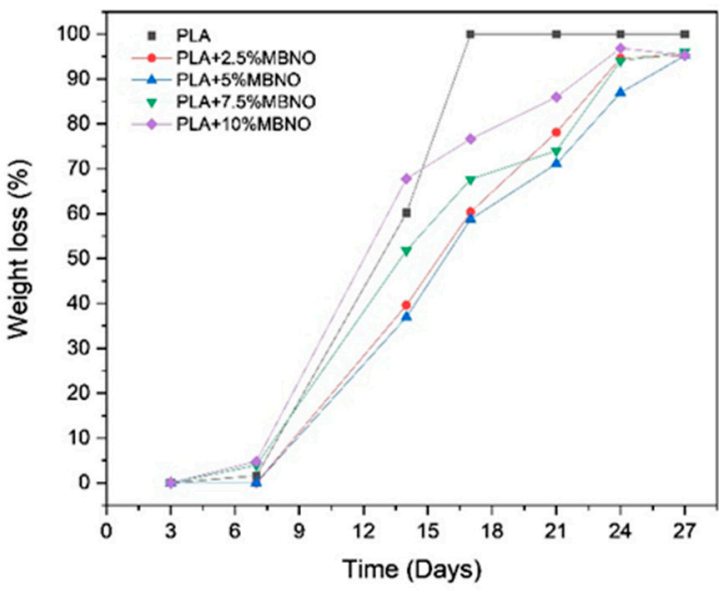

(a)

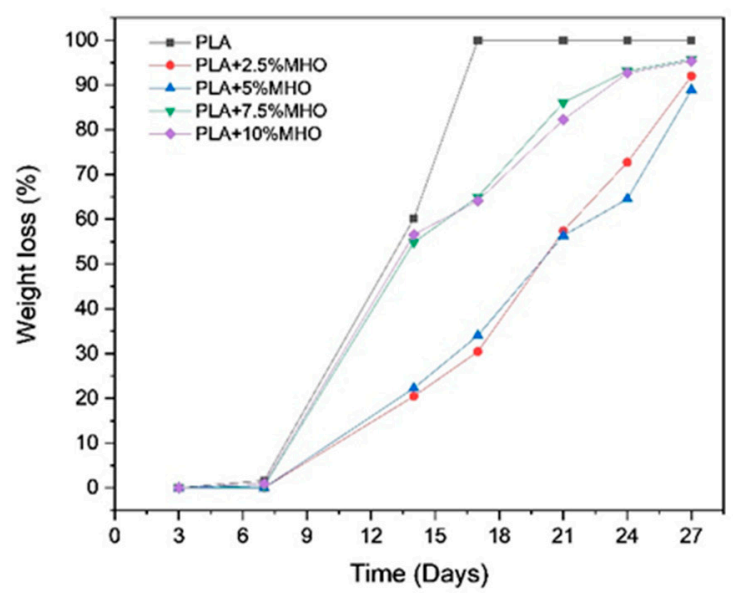

(b)

Figure 13. Weight loss recorded during disintegration test of PLA formulations with MBNO (a) and MHO (b).

\section{Conclusions}

This research work has developed for the first time a maleinized Brazil nut oil (MBNO). This, as well as a maleinized hemp oil (MHO), were introduced into the PLA matrix to study and analyze their effect as bio-based plasticizers. In addition, the results obtained show $\mathrm{MBNO}$ and $\mathrm{MHO}$ provided a similar performance compared with a commercially available maleinized linseed oil (MLO), demonstrating its potential. For example, the elongation at break of neat PLA is $7.4 \%$, which is quite low given its brittleness. With the addition of $\mathrm{MBNO}$ and $\mathrm{MHO}$, an improvement of $643 \%$ and $771 \%$, respectively, was achieved. On the other hand, with values higher than $7.5 \mathrm{phr} \mathrm{MBNO}$, a decrease in the elongation at break was observed due to the anti-plasticizing effect produced by saturation in the mixture. In terms of absorbed impact energy, a $20 \%$ higher value was obtained with the addition of $7.5 \mathrm{phr}$ MBNO and $46 \%$ higher with $10 \mathrm{phr}$ MHO compared to unplasticized PLA. In addition, mechanical properties such as tensile strength do not decrease, as both maleinized oils provide an improvement in the mobility of PLA chains and an increase in free volume, increasing the degree of crystallinity and thus counteracting the plasticizing effect that would decrease these properties. Thermal parameters, such as $\mathrm{T}_{\mathrm{g}}$, show a decreasing influence with the presence of these bio-plasticizers developed, but not drastically. Finally, the disintegration test under composting conditions showed that the addition of MBNO and MHO, although slightly delaying the process, did not lead to a loss of the biodegradability of PLA. Therefore, both MBNO and MHO are shown as potential bio-plasticizers of organic origin to increase the ductility of PLA without affecting its mechanical properties and not affecting its biodegradability, which makes them two bio-plasticizers of interest for industrial applications.

Author Contributions: Conceptualization, A.P.-N. and V.F.; methodology, A.P.-N., A.L.-C. and I.D.-C.; validation, D.G.-G., J.M.F. and V.F; formal analysis, A.P.-N., A.L.-C. and I.D.-C.; investigation, A.P.-N. and A.L.-C.; resources, D.G.-G. and V.F.; data curation, D.G.-G.; writing-original draft preparation, A.P.-N., J.M.F. and D.G.-G.; writing-review and editing, V.F.; visualization, D.G.-G.; supervision, J.M.F. and V.F.; project administration, V.F.; funding acquisition, J.M.F., D.G.-G. and V.F. All authors have read and agreed to the published version of the manuscript.

Funding: I.D.-C. wants to thank Universitat Politècnica de València for his FPI grant (PAID-2019SP20190013) and Generalitat Valenciana (GVA) for his FPI grant (ACIF/2020/233). J.M.F. thanks the postdoc contract (APOSTD/2019/122) Generalitat Valenciana (2019-2021).

Institutional Review Board Statement: Not applicable.

Informed Consent Statement: Not applicable. 
Acknowledgments: The authors want to thank the Cátedra FACSA-FOVASA of Water, Waste and Circular Economy for their support, which promotes and supports training, dissemination, innovation, social responsibility and entrepreneurship activities in the field of circular economy and has kindly provided the necessary chemical reagents.

Conflicts of Interest: The authors declare no conflict of interest.

\section{References}

1. Report of the World Commission on Environment and Development: Our common future; Development and International Co-operation: Environment, Oxford University Press: London, UK, 1987; Volume 10, p. 300.

2. An Analysis of European Plastics Production, Demand and Waste Data; Plastics Europe: Brussels, Belgium, $2020 ;$ p. 64.

3. Rai, P.; Mehrotra, S.; Priya, S.; Gnansounou, E.; Sharma, S. Recent advances in the sustainable design and applications of biodegradable polymers. Bioresour. Technol. 2021, 325, 124739. [CrossRef]

4. Pasaoglu, M.E.; Koyuncu, I. Substitution of Petroleum-Based Polymeric Materials Used in the Electrospinning Process with Nanocellulose: A Review and Future Outlook. Chemosphere 2020, 269, 128710. [CrossRef]

5. Carbonell-Verdu, A.; Garcia-Garcia, D.; Dominici, F.; Torre, L.; Sanchez-Nacher, L.; Balart, R. PLA films with improved flexibility properties by using maleinized cottonseed oil. Eur. Polym. J. 2017, 91, 248-259. [CrossRef]

6. Mittal, V.; Akhtar, T.; Matsko, N. Engineering. Mechanical, thermal, rheological and morphological properties of binary and ternary blends of PLA, TPS and PCL. Macromol. Mater. Eng. 2015, 300, 423-435. [CrossRef]

7. Chivrac, F.; Pollet, E.; Averous, L. Progress in nano-biocomposites based on polysaccharides and nanoclays. Mater. Sci. Eng. R Rep. 2009, 67, 1-17. [CrossRef]

8. Biodegradable Plastics Market Is Expected to Grow USD 8971.32 Million by the End of 2025; Valuates Reports; PR Newswire: Bangalore, India, 2020.

9. Yu, Y.; Cheng, Y.; Ren, J.; Cao, E.; Fu, X.; Guo, W. Plasticizing effect of poly(ethylene glycol)s with different molecular weights in poly(lactic acid)/starch blends. J. Appl. Polym. Sci. 2015, 132, 132. [CrossRef]

10. Arrieta, M.P.; Fortunati, E.; Dominici, F.; Rayón, E.; López, J.; Kenny, J.M. PLA-PHB/cellulose based films: Mechanical, barrier and disintegration properties. Polym. Degrad. Stab. 2014, 107, 139-149. [CrossRef]

11. Fortunati, E.; Armentano, I.; Iannoni, A.; Kenny, J.M. Development and thermal behaviour of ternary PLA matrix composites. Polym. Degrad. Stab. 2010, 95, 2200-2206. [CrossRef]

12. Ferri, J.M.; Garcia-Garcia, D.; Sánchez-Nacher, L.; Fenollar, O.; Balart, R. The effect of maleinized linseed oil (MLO) on mechanical performance of poly (lactic acid)-thermoplastic starch (PLA-TPS) blends. Carbohydr. Polym. 2016, 147, 60-68. [CrossRef] [PubMed]

13. Carrasco, F.; Gámez-Pérez, J.; Santana, O.; Maspoch, M. Processing of poly (lactic acid)/organomontmorillonite nanocomposites: Microstructure, thermal stability and kinetics of the thermal decomposition. Chem. Eng. J. 2011, 178, 451-460. [CrossRef]

14. Nampoothiri, K.M.; Nair, N.R.; John, R. An overview of the recent developments in polylactide (PLA) research. Bioresour. Technol. 2010, 101, 8493-8501. [CrossRef]

15. Wee, Y.-J.; Kim, J.-N.; Ryu, H.-W. Biotechnological production of lactic acid and its recent applications. Biotechnology 2006, 44, 163-172.

16. Chieng, B.W.; Ibrahim, N.A.; Yunus, W.M.Z.W.; Hussein, M.Z. Poly (lactic acid)/poly (ethylene glycol) polymer nanocomposites: Effects of graphene nanoplatelets. Polymers 2014, 6, 93-104. [CrossRef]

17. Müller, P.; Bere, J.; Fekete, E.; Móczó, J.; Nagy, B.; Kállay, M.; Gyarmati, B.; Pukánszky, B. Interactions, structure and properties in PLA/plasticized starch blends. Polymers 2016, 103, 9-18. [CrossRef]

18. Malwela, T.; Ray, S.S. Enzymatic degradation behavior of nanoclay reinforced biodegradable PLA/PBSA blend composites. Int. J. Biol. Macromol. 2015, 77, 131-142. [CrossRef] [PubMed]

19. Ghorui, S.; Bandyopadhyay, N.; Ray, D.; Sengupta, S.; Kar, T. Industrial Crops and Products. Use of maleated castor oil as biomodifier in unsaturated polyester resin/fly ash composites. Ind. Crop. Prod. 2011, 34, 893-899. [CrossRef]

20. Meier, M.A.; Metzger, J.O.; Schubert, U.S.J. Plant oil renewable resources as green alternatives in polymer science. Chem. Soc. Rev. 2007, 36, 1788-1802. [CrossRef] [PubMed]

21. Maisonneuve, L.; Lebarbé, T.; Grau, E.; Cramail, H.J. Structure-Properties relationship of fatty acid-based thermoplastics as synthetic polymer mimics. Polym. Chem. 2013, 4, 5472-5517. [CrossRef]

22. Liao, C.; Liu, F.; Alomirah, H.; Loi, V.D.; Mohd, M.A.; Moon, H.-B.; Nakata, H.; Kannan, K.J.E.s. Bisphenol S in urine from the United States and seven Asian countries: Occurrence and human exposures. Technology 2012, 46, 6860-6866. [CrossRef]

23. Janković, M.R.; Govedarica, O.M.; Sinadinović-Fišer, S.V.J. The epoxidation of linseed oil with in situ formed peracetic acid: A model with included influence of the oil fatty acid composition. Ind. Crop. Prod. 2020, 143, 111881. [CrossRef]

24. Carbonell-Verdu, A.; Samper, M.D.; Garcia-Garcia, D.; Sanchez-Nacher, L.; Balart, R.J. Plasticization effect of epoxidized cottonseed oil (ECSO) on poly (lactic acid). Ind. Crop. Prod. 2017, 104, 278-286. [CrossRef]

25. Stanzione, J., III; La Scala, J. Sustainable polymers and polymer science: Dedicated to the life and work of Richard P. Wool. J. Appl. Polym. Sci. 2016, 133. [CrossRef]

26. Garcia-Garcia, D.; Ferri, J.M.; Montanes, N.; Lopez-Martinez, J.; Balart, R.J. Plasticization effects of epoxidized vegetable oils on mechanical properties of poly (3-hydroxybutyrate). Polym. Int. 2016, 65, 1157-1164. [CrossRef] 
27. Chieng, B.W.; Ibrahim, N.A.; Then, Y.Y.; Loo, Y.Y.J. Epoxidized vegetable oils plasticized poly (lactic acid) biocomposites: Mechanical, thermal and morphology properties. Molecules 2014, 19, 16024-16038. [CrossRef]

28. Ferri, J.M.; Garcia-Garcia, D.; Montanes, N.; Fenollar, O.; Balart, R.J. The effect of maleinized linseed oil as biobased plasticizer in poly (lactic acid)-based formulations. Polym. Int. 2017, 66, 882-891. [CrossRef]

29. Quiles-Carrillo, L.; Blanes-Martínez, M.; Montanes, N.; Fenollar, O.; Torres-Giner, S.; Balart, R.J. Reactive toughening of injectionmolded polylactide pieces using maleinized hemp seed oil. Eur. Polym. J. 2018, 98, 402-410. [CrossRef]

30. Chunhieng, T.; Goli, T.; Piombo, G.; Pioch, D.; Brochier, J.; Montet, D. Recent analysis of the composition of Brazil nut Bertholletia excelsa. Amaz. Bois Trop. 2004, 280.

31. Cornelio-Santiago, H.P.; Bodini, R.B.; de Oliveira, A.L.J. Potential of Oilseeds Native to Amazon and Brazilian Cerrado Biomes: Benefits, Chemical and Functional Properties, and Extraction Methods. J. Am. Oil Chem. Soc. 2021, 98, 3-20. [CrossRef]

32. Mikulcová, V.; Kašpárková, V.; Humpolíček, P.; Buňková, L.J. Formulation, characterization and properties of hemp seed oil and its emulsions. Molecules 2017, 22, 700. [CrossRef]

33. Abuzaytoun, R.; Shahidi, F.J. Oxidative stability of flax and hemp oils. J. Am. Oil Chem. Soc. 2006, 83, 855-861. [CrossRef]

34. Ferri, J.M.; Fenollar, O.; Jorda-Vilaplana, A.; García-Sanoguera, D.; Balart, R.J. Effect of miscibility on mechanical and thermal properties of poly (lactic acid)/polycaprolactone blends. Polym. Int. 2016, 65, 453-463. [CrossRef]

35. Eren, T.; Küsefoğlu, S.H.; Wool, R.J. Polymerization of maleic anhydride-modified plant oils with polyols. J. Appl. Polym. Sci. 2003, 90, 197-202. [CrossRef]

36. Quiles-Carrillo, L.; Montanes, N.; Sammon, C.; Balart, R.; Torres-Giner, S.J. Compatibilization of highly sustainable polylactide/almond shell flour composites by reactive extrusion with maleinized linseed oil. Ind. Crop. Prod. 2018, 111, 878-888. [CrossRef]

37. Ernzen, J.R.; Bondan, F.; Luvison, C.; Henrique Wanke, C.; De Nardi Martins, J.; Fiorio, R.; Bianchi, O.J. Structure and properties relationship of melt reacted polyamide 6/malenized soybean oil. J. Appl. Polym. Sci. 2016, 133, 133. [CrossRef]

38. Mikus, P.-Y.; Alix, S.; Soulestin, J.; Lacrampe, M.; Krawczak, P.; Coqueret, X.; Dole, P.J. Deformation mechanisms of plasticized starch materials. Carbohydr. Polym. 2014, 114, 450-457. [CrossRef]

39. Daniels, P.H.J. Brief overview of theories of PVC plasticization and methods used to evaluate PVC-plasticizer interaction. J. Vinyl Addit. Technol. 2009, 15, 219-223. [CrossRef]

40. Garcia-Garcia, D.; Carbonell-Verdu, A.; Arrieta, M.; López-Martínez, J.; Samper, M.J. Stability. Improvement of PLA film ductility by plasticization with epoxidized karanja oil. Polym. Degrad. Stab. 2020, 179, 109259. [CrossRef]

41. Cui, L.; Zhang, R.; Wang, Y.; Zhang, C.; Guo, Y.J. Effect of plasticizer poly (ethylene glycol) on the crystallization properties of stereocomplex-type poly (lactide acid). Wuhan Univ. J. Nat. Sci. 2017, 22, 420-428. [CrossRef]

42. Moraru, C.; Lee, T.C.; Karwe, M.; Kokini, J.J. Plasticizing and Antiplasticizing Effects of Water and Polyols on a Meat-Starch Extruded Matri. J. Food Sci. 2002, 67, 3396-3401. [CrossRef]

43. Balart, J.; Fombuena, V.; Fenollar, O.; Boronat, T.; Sánchez-Nacher, L.J. Processing and characterization of high environmental efficiency composites based on PLA and hazelnut shell flour (HSF) with biobased plasticizers derived from epoxidized linseed oil (ELO). Compos. Part B Eng. 2016, 86, 168-177. [CrossRef]

44. Garcia-Campo, M.J.; Quiles-Carrillo, L.; Masia, J.; Reig-Pérez, M.J.; Montanes, N.; Balart, R.J. Environmentally friendly compatibilizers from soybean oil for ternary blends of poly (lactic acid)-PLA, poly ( $\varepsilon$-caprolactone)-PCL and poly (3-hydroxybutyrate)-PHB. Materials 2017, 10, 1339. [CrossRef]

45. Dobircau, L.; Delpouve, N.; Herbinet, R.; Domenek, S.; Le Pluart, L.; Delbreilh, L.; Ducruet, V.; Dargent, E.J. Molecular mobility and physical ageing of plasticized poly (lactide). Polym. Eng. Sci. 2015, 55, 858-865. [CrossRef]

46. Dominguez-Candela, I.; Ferri, J.M.; Cardona, S.C.; Lora, J.; Fombuena, V.J. Dual Plasticizer/Thermal Stabilizer Effect of Epoxidized Chia Seed Oil (Salvia hispanica L.) to Improve Ductility and Thermal Properties of Poly (Lactic Acid). Ploymers 2021, $13,1283$. [CrossRef] [PubMed]

47. Xiong, Z.; Li, C.; Ma, S.; Feng, J.; Yang, Y.; Zhang, R.; Zhu, J.J. The properties of poly (lactic acid)/starch blends with a functionalized plant oil: Tung oil anhydride. Carbohydr. Polym. 2013, 95, 77-84. [CrossRef] [PubMed]

48. Silverajah, V.; Ibrahim, N.A.; Zainuddin, N.; Yunus, W.M.Z.W.; Hassan, H.A.J. Mechanical, thermal and morphological properties of poly (lactic acid)/epoxidized palm olein blend. Molecules 2012, 17, 11729-11747. [CrossRef]

49. Santos, E.F.; Oliveira, R.V.; Reiznautt, Q.B.; Samios, D.; Nachtigall, S.M.J. Sunflower-oil biodiesel-oligoesters/polylactide blends: Plasticizing effect and ageing. Polym. Test. 2014, 39, 23-29. [CrossRef]

50. Fukushima, K.; Tabuani, D.; Abbate, C.; Arena, M.; Ferreri, L.J. Effect of sepiolite on the biodegradation of poly (lactic acid) and polycaprolactone. Polym. Degrad. Stab. 2010, 95, 2049-2056. [CrossRef]

51. Ray, S.S.; Yamada, K.; Ogami, A.; Okamoto, M.; Ueda, K.J. New polylactide/layered silicate nanocomposite: Nanoscale control over multiple properties. Macromol. Rapid Commun. 2002, 23, 943-947. [CrossRef]

52. Tokiwa, Y.; Calabia, B.P.J. Biodegradability and biodegradation of poly (lactide). Appl. Microbiol. Biotechnol. 2006, 72, 244-251. [CrossRef]

53. Balart, J.; Montanes, N.; Fombuena, V.; Boronat, T.; Sánchez-Nacher, L.J. Disintegration in compost conditions and water uptake of green composites from poly (lactic acid) and hazelnut shell flour. J. Polym. Environ. 2018, 26, 701-715. [CrossRef] 